\title{
THE PERCEPTION OF PROFESSIONALS FROM THE HEALTH AREA REGARDING THEIR TRAINING AS LECTURERS ${ }^{1}$
}

\author{
Patrícia Treviso², Bartira Ercília Pinheiro da Costa ${ }^{3}$
}

\begin{abstract}
${ }^{1}$ This article is extracted from the dissertation - Perception of professionals from the area of health regarding the training, work and satisfaction in their work as lecturers', presented to the Postgraduate Program in Medicine and Health Sciences, Pontificia Universidade Católica do Rio Grande do Sul, in 2015.

2 Ph.D. in Medicine and Health Sciences. Professor, Centro Universitário Metodista. Porto Alegre, Rio Grande do Sul, Brazil. Email: ptreviso15@gmail.com

${ }^{3}$ Ph.D. in Cellular and Molecular Biology. Professor, Faculty of Medicine and of the Postgraduate Program in Medicine and Health Sciences, Pontifícia Universidade Católica do Rio Grande do Sul. Porto Alegre, Rio Grande do Sul, Brazil. Email: bart@pucrs.br
\end{abstract}

\begin{abstract}
Objective: to investigate the perception of professionals from the health area regarding training for their teaching practice.

Method: it is an exploratory, descriptive, prospective study, with qualitative analysis. The sample was made up of 85 lecturers from 10 undergraduate courses in the area of health, from a private Higher Education Institution in the Brazilian State of Rio Grande do Sul. Data collection was undertaken in 2014, through a questionnaire using the Qualtrics tool. Content analysis was used for analyzing the data.

Results: the study made it possible to identify how the participants perceive the health professional: in general, as a health specialist able to work in different areas, but who lacks pedagogical training to undertake teaching. It was observed, furthermore, that these professionals seek development in the pedagogical aspects through formal, informal and non-formal education.

Conclusion: the teaching practice of health professionals requires skills that go beyond the simple knowledge of contents.

DESCRIPTORS: Education. Higher education. Continuing health personnel.

\section{PERCEPÇÃO DE PROFISSIONAIS DA ÁREA DA SAÚDE SOBRE A FORMAÇÃO EM SUA ATIVIDADE DOCENTE}

RESUMO

Objetivo: conhecer a percepção de profissionais da área da saúde sobre a formação em sua atividade docente.

Método: estudo exploratório, descritivo, prospectivo, com análise qualitativa. Amostra composta por 85 professores de dez cursos de graduação na área da saúde de uma Instituição de Ensino Superior privada do Estado do Rio Grande do Sul. A coleta dos dados foi realizada em 2014, por meio de questionário via ferramenta Qualtrics. Para o tratamento dos dados, utilizou-se análise de conteúdo.

Resultados: o estudo permitiu identificar como os participantes percebem o profissional da saúde: de modo geral, especialista em saúde, estando apto para atuar em suas diferentes áreas, porém carecendo de formação pedagógica para exercer a docência. Constatou, ainda, que esses profissionais buscam desenvolvimento nos aspectos pedagógicos por meio de educação formal, informal e não formal.

Conclusão: a atuação docente do profissional de saúde exige habilidades que ultrapassam o conhecimento de conteúdos.

DESCRITORES: Ensino superior. Educação continuada. Profissionais da saúde. 


\title{
PERCEPCIÓN DE PROFESIONALES DEL ÁREA DE LA SALUD SOBRE LA FORMACIÓN EN SU ACTIVIDAD DOCENTE
}

\begin{abstract}
RESUMEN
Objetivo: conocer la percepción de profesionales del área de la salud sobre la formación en su actividad docente.

Método: estudio exploratorio, descriptivo, prospectivo, con análisis cualitativo. Muestra compuesta por 85 profesores de diez cursos de graduación en el área de la salud de una Institución de Enseñanza Superior privada del Estado de Rio Grande do Sul. La recolección de los datos fue realizada en 2014, por medio de cuestionario vía herramienta Qualtrics. Para el tratamiento de los datos, se utilizó análisis de contenido.

Resultados: el estudio permitió identificar como los participantes perciben el profesional de la salud: de modo general es percibido como un especialista en salud que está apto para actuar en sus diferentes áreas, pero que carece de formación pedagógica para ejercer la docencia. Se constató aún que esos profesionales buscan el desarrollo en aspectos pedagógicos a través de educación formal, informal y no formal. Conclusión: la actuación docente del profesional de salud exige habilidades que ultrapasan el conocimiento de contenidos.

DESCRIPTORES: Educación superior. Educación continua. Personal de salud.
\end{abstract}

\section{INTRODUCTION}

The training and development of lecturers in the health area has been the focus of various discussions, addressing aspects such as the pedagogical practice, the curricula, and their didactic training, given their importance for training professionals who are better qualified. ${ }^{1-2}$ The National Curricular Guidelines (DCNs) have advised that it is necessary to train health professionals who are humane, generalist, critical and reflexive. In this line of guidance, the challenge is to break with the fragmented and technicist model of training, seeking to produce health professionals who are more humane, and who have the conditions to work as part of a team, in an integrated way and focusing on the comprehensive character of the healthcare. ${ }^{3}$

The health professionals' work is not restricted to care alone. It also encompasses research, management and education. One of the sides of this quadrilateral - education - involves activities with the patient, family, society and care team, as well as the training itself of new professionals, whether at the technical, undergraduate or postgraduate levels. Just as it is necessary to have specific training to work in any other area, practice in education also requires preparation. The profession of lecturer, following the model of other professions which define their basis of knowledge in systematic terms, requires preparation, given that the role of teacher is not defined by the simple mastery of content, but by the use and mobilization of these knowledges and in what one does such that this content may be taught and learnt. ${ }^{4}$

This concern with the lecturer's training is not found only in Brazil. In 2007, the European Commission published a communiqué which reflects the concern over the need to improve the quality of teacher training in the European Union, revealing that this training is an indispensable condition for quality professional training; also emphasizing that the role of teacher is increasingly difficult and complex, with increasingly demanding work environments. ${ }^{5}$

The UNESCO World Declaration on Higher Education for the Twenty-First Century: Vision and Action ${ }^{6}$ argues that that the mission of Higher Education Institutions (HEI) is to produce people who are highly qualified and who are responsible citizens, as well as to support the valorization of lifelong education. In this perspective, the future of higher education in Brazil is to be found through the innovations advised by the UNESCO declaration, which evidences the need for the continuing training of lecturers..$^{6-7}$

The pedagogical training of the health professional who works as a lecturer is an issue currently under discussion, and is broad and complex, confirming the relevance of this study's undertaking. In this scenario, the study aims to investigate the perception of professionals from the health area regarding training in their teaching practice.

\section{METHOD}

This is an exploratory, descriptive study, using qualitative analysis. The sample was made up of lecturers from undergraduate courses in the area of health (Biomedicine, Physical Education, Nursing, Pharmacy, Physiotherapy, Speech Therapy, Nutrition, Psychology, Social Work and Occupational Therapy) from a private HEI in the Brazilian State of Rio Grande do Sul (RS). All of the lecturers $(n=120)$ from these courses were invited to participate, with 85 accepting.

The inclusion criteria were to be working as lecturers on one of the HEI's undergraduate courses in the area of health where the study was undertaken, and to have been trained at higher education 
level on a course in the area of human health. The exclusion criteria referred to lecturers whose training was outside the area of health, who worked on the courses included in this study.

Data collection was undertaken in May - July 2014. For this, a questionnaire was developed, structured with open and closed questions, and which placed emphasis on the teacher training, as well as questions relating to the participants' profile. The questionnaire was the same for all of the professors, and was presented using the Qualtrics tool (http:/ / www.qualtrics.com/login/). In the collection - which was undertaken by sending emails to the lecturers - the study which was intended to be undertaken was explained, as was how the questionnaire could be accessed in order to be answered (by accessing the link provided in the body of the email), what the objectives were, how data collection would be achieved and the description of the study's ethical principles. In addition, the Terms of Free and Informed Consent (TFIC) were annexed to the correspondence. In the body of the email, it was emphasized that the TFIC was annexed. It is highlighted that each professor's acceptance took place through filling out the questionnaire, this being based on the principle that the participant accepted to participate in the study. The technique used for data collection - the Qualtrics questionnaire - does not allow the participants to be identified, even by the researcher.

Before data collection began, a pilot test was undertaken, involving the participation of nine lecturers who worked on health courses in different HEIs, as well as one lecturer from the area of Pedagogy, totaling 10 professors, which made it possible to make fine adjustments in the data collection instrument.

Content analysis ${ }^{8}$ was used to consider the data, involving three stages: pre-analysis, exploration of the material and treatment of the results obtained, and inference and interpretation. The analysis made it possible to construct two categories: Pedagogical training to act as a lecturer, and Ways of seeking qualification as a lecturer (T1 and $\mathrm{T} 2$, respectively).

The units of meaning used and analyzed in each category were identified using the letter ' $\mathrm{T}$ ' for 'training', followed by cardinal numbers referring to the category. This, in its turn, was followed by a decimal point and a cardinal number in order to identify the order of the participant's insertion in the study. For example: T1.23 - T (training), 1 (first category), 23 (twenty-third participant in the study).
It is emphasized that the study was guided by the stipulations of Resolution 466/2012 of the National Health Council, which establishes parameters for research involving human beings. The study was conducted in accordance with the ethical standards required. ${ }^{9}$

The research project was submitted to, and approved by, the Research Ethics Committees of the institutions involved (proponent and co-participant, under Opinions N.s 510,568 and 605,387-0, respectively.

\section{RESULTS AND DISCUSSION}

In relation to the characterization of the sample, this was made up of 85 participants, corresponding to $70.8 \%$ of the population, of whom 60 (71\%) were female and $25(29 \%)$, male. The participants' mean age was 40 years old, the oldest participant being aged 60, and the youngest, 25 .

The participants' distribution was different regarding the course on which they worked. Out of the total of ten courses, $100 \%$ of the lecturers participated from two - Pharmacy and Occupational Therapy. In the case of Nursing and Physiotherapy, $91 \%$ of the lecturers participated, while for Social Work the figure was $83 \%$, for Nutrition it was $80 \%$, for Speech Therapy it was $67 \%$, for Biomedicine it was $55 \%$, for Psychology it was $45 \%$, and for Physical Education, responses were received from $25 \%$ of the course's lecturers. The most significant participation was from the courses in Nursing and Physiotherapy, which, together, represented $49 \%$ of the total of the participants, there being 22 lecturers from the course in Nursing and 23 from the course in Physiotherapy.

Regarding the participants' level of training when they began their careers as lecturers, $20 \%$ of these professionals had nothing more than their undergraduate degree. When this distribution is compared the professors' current levelling data, it may be observed that the postgraduate training was actively undertaken by a significant number of lecturers, given that in the data collection period, all had undertaken a postgraduate course of the lato or stricto sensu type, there being 55 participants (the majority) with a Master's degree (64.7\%), 23 with a doctorate $(27.1 \%)$ and four with a post-doctorate $(4.7 \%)$; three lecturers (the minority) had undertaken just a specialization course (3.5\%). This context is in line with the Law of Directives and Bases of National Education, regarding the requirement that, at the minimum, one third of the teaching body should have an MA or doctorate. ${ }^{10}$ Regarding the time they 
had worked in the specific area in which they had graduated, $72 \%$ had worked there for more than five years, and, of these, $24 \%$ had worked there for over 20 years. These are fairly significant numbers, which show major experience in the area in which they first graduated. Only $5 \%$ of the participants had never worked in the specific area in which they graduated. Lecturers who continued to work in the area in which they had initially trained, besides lecturing, corresponded to $65 \%$ of the participants.

In relation to the length of work in lecturing, $82 \%$ were professionals with more than three years' experience, $24 \%$ had worked in the area for more than five years, $7 \%$ had worked for up to one year, and $13 \%$ of the participants had worked there for over 20 years. These data lead one to consider that the group participating has experience in the area of lecturing, a fact which may contribute to the quality of the teaching.

Content analysis was used for consideration of the responses deriving from the open questions. The description and categorization of accounts and the inference, and, later, the interpretation of the content, were necessary.

\section{T1 - Pedagogical training to work as a lecturer}

The term 'lecturer' means "relating to teaching and the person who teaches", ${ }^{11: 259}$ and the term 'teacher' means "the person who teaches an art, a science, a technique, a course; whose profession is to give classes in the school or university; a lecturer; an individual who is specialized in something; who exercises the role of teaching or has a diploma or title for exercising this profession" ${ }^{11: 607}$ Attention is called to the fact that, in the description, the teacher is an individual who is specialized in a certain area, that is, somebody who has mastery in the knowledge of a specified topic, technique or subject. The health professionals of the different courses fit into this description. It is asked, however, whether this knowledge is sufficient for the professional to perform the role of lecturer, or whether a specific training to teach is necessary.

The undergraduate degree allows the individual to work in a specified profession in which she has specialized, ${ }^{12}$ but does not necessarily train her to teach this profession. Although on some courses or in some higher education institutions there is a concern that the student should learn aspects of education, the undergraduate course does not aim to train the individual to act as a teacher, but rather to work in the specific area in which she graduates
- such as Nursing, Physiotherapy, Psychology or others, as observed by the participants in the following statements: [...] The challenges posed by lecturing go beyond issues relating to the specific area in which you trained [...] (T1.8); [...] In the basic training, there wasn't a single course related [to teaching]. We left as graduates and became lecturers (T1.41).

The participants emphasized that the undergraduate degree gave them the title of 'graduates' but did not train them to work as lecturers. It is to be expected, therefore, that the majority of those graduating enter the labor market to work in the specific area in which they trained. This may be in health institutions, laboratories, clinics or others, seeking to perform what they learnt and to obtain experience in order to strive for new horizons, whether through wanting to investigate other areas, extend their knowledge or even seek to increase the financial return through their work. However, in various areas of health, clinical practice and care practice have a financial return which is low in comparison with that produced by lecturing. As a result, lecturing comes to be seen as a work niche desired by many. However, they begin their lecturing career without the necessary preparation that this role demands. ${ }^{13}$ And although experience as a health professional is an important factor for entering this market, in order to exercise the job of lecturer, it is necessary to develop skills. "There seems to be a belief that, in the area of health, good practice as a lecturer is closely linked to good professional practice - which is not always the case" ${ }^{\prime 13: 39}$ Both domains are necessary, both in the area of health and of lecturing.

The professors of higher education, who are generally specialists in their area, often lack pedagogical training, both technically and philosophically. There is an understanding that it is enough for the individual to know about something in depth in order to be a lecturer, that is to say, in order to lecture in higher education, what really matters is to have mastery of the knowledge of the specific area in which the person works, it not being necessary to have training as a teacher..$^{14}$ This context, however, is changing, there being a growing concern on the part of HEI lecturers regarding the filling of this gap. ${ }^{14-15}$ The social, political, economic and cultural changes require adaptation from the lecturer in order to work in higher education, besides her commitment to her training and institutional support.

Teaching is one of the oldest professions of all times; however, the study of the practice of teaching is fairly recent. ${ }^{16}$ This involves learning to investigate, learning to do, learning to exist and learning 
to be ${ }_{17}^{17}$ that is, the lecturer needs to have the knowledges involving the content to be taught, needs to know how to do, needs to have the knowledge of how to apply this content and how to teach this to the students and to have the specific skills to carry out the role of lecturer. ${ }^{18-19}$

Experience and technical skill can enable the lecturer to contribute even more in the construction of knowledge, also influencing the confidence to teach what she knows, but it is not enough to exercise the role of lecturer, as some participants indicate: experience of the work practice and skill in care [...] do not train or guarantee the professional skill in sharing knowledge and contributing to the students' learning (T1.1); [...] We cannot teach only through clinical experience [...] (T1.75).

It is necessary to consider the need for didactic knowledge of the content and not only knowledge of the content per $s e,^{20}$ besides the pedagogical knowledge which involves aspects such as the organization of the teaching and learning activities, and management of the group of students. ${ }^{21}$ The teacher needs to teach the content, but not only this. The teacher's role is also to advise, to motivate the student to seek knowledge and meanings, and encourage her to want to learn and not just to seek certification. Some participants also considered that the work as a health professional differs from their work as a lecturer, as it requires distinct skills: the work as a health professional is different from work as a lecturer in the area of health (T1.50).

However, experience in the specific area can contribute to work as a lecturer, qualifying the teaching and allowing the teacher greater security, even more so if added to the teacher training, as one of the study participants indicates: [...] Teacher training, associated [...] with the experience, helps the lecturer [...] (T1.84).

The study shows that the experience in the area of initial training contributes to working as a lecturer, but that this is not sufficient to work in the process of teaching and learning with quality. ${ }^{13}$

The selection processes for lecturers aim for professionals who are specialized in particular areas of health and who have technical-scientific skill, 13,19 in addition to other factors such as the profile of the researcher, personal aspects such as personal posture and presentation and academic title. These aspects are important and certainly contribute to qualify a person as a lecturer, but pedagogical training is important, this being constructed throughout the exercising of the profession, continuously, and which is based in reflection on daily practice. ${ }^{20}$
The stricto sensu training, a criterion for selection to be a lecturer, and to which training as a lecturer is often credited, does not always have this character, given that it depends on the trajectory that each individual takes in their training, such as the topic of the research, the type of study which is undertaken, the objective of the professional life desired, opting for postgraduate courses geared towards - or not - the training of professionals who will work as lecturers, or undertaking courses which seek to qualify the professional to be a lecturer. It is emphasized that "it is overly simplistic to believe that the professional finishes her Masters or doctorate totally trained to work as a lecturer, even if because these courses prioritize training for research and not for working in a classroom". ${ }^{13: 41}$ This can also be observed in the participants' accounts: [...] In general, the postgraduate courses in the area of health are geared more towards training researchers than lecturers. It is important, therefore, to complement the pedagogical training (T1.51).

Professionals who decide to follow an academic career need skills which cannot be acquired instantly, but which are constructed and improved over time, in the exercising of the profession, through courses, lato and stricto sensu postgraduate courses, and others. ${ }^{13}$ The stricto sensu training is a requirement to work in a large number of higher education institutions; it is necessary for these to offer more courses which make it possible to instrumentalize the future teacher to exercise this role, regardless of the her first course. During the postgraduate course, principally, there should be more offering of basic courses in pedagogy, in which they can learn the essential terms and technical criteria to work as lecturers (T1.32).

Courses with pedagogical content should be obligatory on the stricto sensu postgraduate courses, with the aim of instrumentalizing the future lecturer, but, principally, to spur her to seek more general didactic knowledge in order to contribute in a well-qualified way to the teaching and learning.

There is a gap in the performance of lecturers in higher education, related to the pedagogical skill in the process of the construction of knowledge. The teacher has mastery of the content on which she is going to lecture, but does not necessarily have knowledge and skill for mobilizing and working on the knowledges with the students, ${ }^{19}$ because teaching involves specific knowledge, but also pedagogical and didactic knowledges, ${ }^{21}$ as one of the participants emphasizes that [...] knowing the content does not mean that you know how to teach (T1.40). 
In teaching, it is not only the mastery of techniques for giving a specific class; on the contrary, it is a process involving many factors, ranging from planning of the semester and the classes, methodologies and evaluation, among others. [...] Because lecturing requires the professional to have [...] knowledge in teaching, knowing how set out a teaching plan, evaluations, teaching methodology, knowing ways of learning [...] (T1.49).

Having pedagogical and didactic knowledge allows the lecturer to explore the teaching and learning strategies in greater depth, allowing greater closeness between the theory-practice in teaching and the professional practice. ${ }^{22}$ In this way, it qualifies the teacher to work in the different teaching environments, as described by the participants: the pedagogical training qualifies you for teaching, because being an educator requires other skills, besides the technical skill (T1.9); [...] It prepares you and gives you pedagogical support to work in the classroom and in the great variety of situations which are inherent to the classroom (T1.36).

The teacher in higher education, with pedagogical mastery, has more conditions to change her teaching methods and techniques, broadening the possibilities for meeting the students' heterogeneity and learning styles, ${ }^{19}$ which justifies the search for the training of the lecturer which should be based in practical and theoretical issues, which allow reflection on the practice and the theoretical basis which involves the aspects of lecturing. ${ }^{23-24}[\ldots]$ The professional needs study and reflection on her practice, in order to exchange knowledges with the student (T1.29).

The role of teaching is intrinsically linked to the nature of this practice and to the type of specific knowledge necessary for exercising it, this being a profession which requires a vast set of knowledges in the area of education, and which needs to be considered and planned, as "[...] it is far from being spontaneous or resulting automatically from the mastery of the content to be taught and of its explanation [...]". 25:117 disagreeing with the currents of opinion which defend the contentist knowledge as supposedly sufficient for teaching.

One of the participants mentioned the possibility of continuous training covering the pedagogical aspects, adding that, even though there is an initial instruction in the specific courses in the area of health, which happens in various institutions, investing in the development of the lecturer is important to encourage the instrumentalization of the lecturer and the quality of the teaching: [...] Even if there were a significant hourly courseload for initial training in the courses in the area of health, a continuing pedagogical training would still be necessary (T1.58).

The alchemy of the appropriation of knowledges $^{25}$ must take place not only with the student who is learning, but also with the lecturer who is learning, so as to allow her a teaching practice which is more confident and more professional.

\section{T2 - Ways of seeking the qualification of the lecturer}

Learning to teach is a process which must occur throughout the teacher's career. The way that this happens is fairly variable, as, for example, through self-evaluation, making changes in the way of working or resolving situations of conflict, which in some way add knowledge and experience to the lecturer.

Lecturing at the higher education level requires the professional to keep herself up-to-date in the specific area in which she trained through participating in improvement courses, scientific events, specialization, exchanges with colleagues, monitoring and reading periodicals and undertaking research, among others. ${ }^{26}$ The training processes of the professionals from the health area generally concentrate on the technical aspects of the specific profession, on what is important and necessary; however, this is just one of the facets of the exercising of lecturing, being one of the instruments for teaching. ${ }^{14}$

In this study, various means emerged used by the lecturers as tools for qualification as a lecturer, such as, for example, a postgraduate qualification (stricto sensu and lato sensu), reading, study, workshops, courses, organized by the HEI where they work, as well as scientific meetings in their specific area and in the area of education; research and scientific production; assisting on examiners' panels for thesis defence; exchanges with peers, students and the multi-professional team; joining study groups, organizations and associations; placements as a lecturer; professional practice as a form of learning; feedback, both as evaluation from students as from self-assessment, among others, which can be defined as training through formal, informal and non-formal education. From when I started my undergraduate course, I was already thinking about doing a Masters and doctorate. As soon as I finished my undergraduate course, I started on these goals (T2.38). I did my doctoral thesis on Education, and I learned to research in Education (T2.40).

Teachers' professional training gives rise to greater awareness and ability for discernment, 
as well as greater development of their own capacities, and should have regular time available for developing and improving oneself, ${ }^{27}[\ldots]$ study groups, discussions on the professional work (T4.78); participating in pedagogical training activities offered by the institution itself. Participation in events in the specific area. Enrolling myself as a student on various professional training courses (T4.1).

In the teaching institutions, there is also a commitment to invest in the training of lecturers, which impacts on the qualification not only of the lecturer, but also on the lecturer's work with the students, thus improving the teaching and learning process. This is a result which benefits and valorizes the HEI itself. ${ }^{13}$

The teacher requires constant updating, ${ }^{27}$ which requires time and dedication, and distance education has been an important mode of education $^{28}$ making it possible to socialize knowledge with greater breadth and speed. In this study, the undertaking of training through distance learning (DL) was described by one participant as being a modality which benefits the professionals who encounter difficulties in participating in on-site training, due to lack of time. Through training courses using the DL model, due to lack of time for attending onsite classes, seminars, congresses or workshops (T4.71).

As a means of qualifying the teaching team and, as a consequence, the teaching, some universities in various countries have made job security and promotion conditional on their participation in training programs and qualification in lecturing. ${ }^{29}$

Self-teaching, generally speaking, is a training strategy used by health professionals who decide to be lecturers. ${ }^{13}$ That is to say, they seek in their own way to read and study with the aim of overcoming the difficulties they meet in performing the role of lecturer. Commonly, training is considered to be the responsibility of the lecturers themselves ${ }^{29}$ it being up to the lecturer to decide regarding what type of training to seek, when to do it and with what objective; which results in the attendance of this person's individual needs, and not necessarily in meeting the needs of the institution. Nevertheless, for the development of the skills necessary for confronting the challenges found in HEIs, these should think about and implant a training policy focusing on their development and qualification. Reading production on pedagogical training and constantly seeking experience and practical updating. (T4.7); through reading and materials and didactic tools. 'Rehearsing' in the classroom [...] and assessing the result of the method used, according to the course administered (T4.62).
Exchange with peers and/or with students is indicated by the participants as one means of learning and improving one's practice as a lecturer: $[\ldots]$ exchanging ideas with colleagues, assessing positive and negative experiences. Restructuring classes after a negative perception in the group (T4.6); [...] conversations with more experienced colleagues and with the students themselves, so as to obtain support for qualifying the teaching-learning process [...] (T4.38).

The process of training lecturers requires time and space, and reveals that the lecturer is the person mainly responsible for her own continuous training, for example "it is necessary for one to construct a movement of valorization and guidance of the lecturer training in higher education in health." ${ }^{30: 810}$ The knowledge constructed based on reflection and understanding of the teaching practice needs to be valorized, ${ }^{31}$ taking into account " $[. .$.$] that all knowledge implies a process of$ learning and of training". ${ }^{32: 77}$ The investment in the teacher training of health professionals is justified by the importance of both the area of education and of health, which are very closely interwoven and can be used as indicators for assessing the level of a country's development. ${ }^{33}$

The participants emphasized that lack of time is one of the factors which most contribute to nonparticipation in training, followed by other aspects, such as lack of encouragement from the HEI where they work, difficulty in obtaining time off from the HEI to participate, ignorance of the existence of training for lecturers, being obstructed from participating due to personal commitments and the difficult financial situation. They also added that conflicting timetables, a type of approach which is not very attractive or which is undertaken with professionals with little experience also influence the decision not to participate.

These opinions indicate the need for the HEI to organize creative training, which encourages and promotes the lecturers' motivation for participating, adapting and adjusting the language of pedagogy to the different areas of training, so that it may be able therefore genuinely to aggregate knowledge and not frighten away those who participate. In addition to this, the ideas manifested indicate the importance of there being planning and publicizing beforehand, which maximizes the possibility of the lecturers participating. Effective training requires time, dedication and commitment, and cannot be done in a brief or succinct form. ${ }^{28}$ 


\section{CONCLUSION}

The study made it possible to investigate the perception of professionals from the health area regarding training in their activities as lecturers. The participants report that the health professional, generally speaking, is a specialist in this field of work, and is able to work in different areas of health but lacks pedagogical training to work as a lecturer; and, therefore, requires improvement in the aspects of education, encompassing the teaching and learning process, methodologies and didactic method and evaluation, among others.

It was also observed that experience and technical skill in the area of health are important for the teaching process, influencing the confidence for teaching the content and bringing greater meaning and reality to the classroom. However, knowing only the technique or the content is not sufficient to be able to teach; it is also necessary to have mastery in the pedagogical area. The processes for selecting lecturers aim for professionals who are specialists in particular areas of health, and who have lato or stricto sensu training; however, experience in teaching, generally speaking, is not a prerequisite.

It was evidenced that qualification for working as a lecturer takes place in various ways, such as, for example: postgraduate courses; reading; training events organized by the HEI where they work, both in the specific area of training and in the area of education; research and scientific production; exchanges with peers and students; and study groups, among others, which can be defined as training through formal, informal and non-formal education.

\section{REFERENCES}

1. Pinto JBT, Pepe AM. A formação do enfermeiro: contradições e desafios à prática pedagógica. Rev Latino-Am Enfermagem [Internet]. 2007 [cited 2015 May 5];15(1):120-6. Available from: http://www. scielo.br/pdf/rlae/v15n1/pt_v15n1a18.pdf

2. Freire LIF, Fernandez C. O professor universitário novato: tensões, dilemas e aprendizados no início da carreira docente. Ciênc Educ [Internet]. 2015 [cited 2015 May 5]; 21(1):255-72. Available from: http://www.scielo.br/pdf/ciedu/v21n1/1516-7313ciedu-21-01-0255.pdf

3. Rossoni E, Lampert J. Formação de profissionais para o Sistema Único de Saúde e as diretrizes curriculares. Bol Saúde [Internet]. 2004 [cited 2015 May 5]; 18(1):87-98. Availablefrom: http://www.boletimdasaude.rs.gov.br/ download/20140521092044v18n1_09formacaoprof.pdf

4. Shulman, LS. Knowledge and teaching: foundations of the new reform. Harvard Edu
Rev [Internet]. 1987 [cited 2015 May 5];57(1):1-23. Available from: http://www.peaunesco.com. br/encontro2013/SHULMAN_Knowledge_and_ Teaching_\%28HarvardEdReview1987\%29.pdf

5. Ministério da Educação (PT). Desenvolvimento profissional de professores para a qualidade e para a equidade da aprendizagem ao longo da vida [página na Internet]. Conferência promovida no âmbito da Presidência Portuguesa do Conselho da União Européia. Lisboa (PT): Ministério da Educação; 2007 [cited 2015 May 8]. Available from: http://www. eu2007.min edu.pt/np4/27.html.

6. Organização das Nações Unidas para a educação, a ciência e a cultura. Declaração mundial sobre educação superior no século XXI: visão e ação [página na Internet]. Paris (FR): UNESCO; 1998 [cited $2015 \mathrm{Mar}$ 8]. Available from: http:/ / www.direitoshumanos.usp. br/index.php/Direito-a-Educa\%C3\%A7\%C3\%A3o/ declaracao-mundial-sobre-educacao-superior-noseculo-xxi-visao-e-acao.html

7. Masetto MT. Educação e futuro superior no Brasil. Educ Futuro [Internet]. 2012 [cited 2015 Mar 8]; (27):201-15. Available from: dialnet.unirioja.es/ descarga/articulo/4060946.pdf

8. Bardin L. Análise de conteúdo. São Paulo: Edições 70; 2011.

9. Ministério da Educação (BR), Conselho Nacional de Educação. Resolução no 466, de 12 de dezembro de 2012. Aprova normas regulamentadoras de pesquisas envolvendo seres humanos. Diário Oficial da União [Internet]. 2013 Jun [cited 2015 Mar 10]; 1:59. Available from: conselho.saude.gov.br/resolucoes/2012/ Reso466.pdf

10. Brasil. Lei de Diretrizes e Base da Educação Nacional [página na Internet]. Brasília: Senado Federal; 2005 [cited 2015 Apr 09]. Available from: www.senado.leg. br/bdsf/bitstream/handle/id/70320/65.pdf

11. Houaiss A, Villar, MS, Franco, FMM. Minidicionário Houaiss de Língua Portuguesa. $3^{\mathrm{a}} \mathrm{ed}$. Rio de Janeiro: Objetiva; 2009.

12. Tardif M. Saberes profissionais dos professores e conhecimentos universitários. Rev Bras Educ [Internet]. 2000 [cited 2015 Apr 09]; 13(5):5-24. Available from: Available from: anped.org.br/rbe/ rbedigital/.../RBDE13_05_MAURICE_TARDIF.pdf

13. Dallacosta FM, Antonello ICF, Lopes MHI. Docência em saúde: breve reflexão sobre a prática profissional. Rev Cient CENSUPEG [Internet]. 2014 [cited 2015 Apr 09]; (3):38-44. Available from: http:// revistacientifica.censupeg.com.br/ojs/index.php/ RevistaCientificaCENSUPEG/article/view/157/60

14. Rozendo CA, Casagrande LDR, Schneider JF, Pardini, LC. Uma análise das práticas docentes de professores universitários da área de saúde. Rev Latino-Am [Internet]. Enfermagem. 1999 [cited 2015 Apr 10]; 7(2):15-23. Available from: www.scielo.br/pdf/rlae/ v7n2/13457.pdf 
15. Jarauta-Borrasca B, Medina-Moya JL. La formación pedagógica inicial del profesorado universitario: repercusión en las concepciones y prácticas docentes. Magis [Internet]. 2009 [cited 2015 Apr 10]; 1(2):357-70. Available from: www.redalyc.org/ pdf/2810/281021548011.pdf

16. Backes VMS, Moyá JLM, Prado ML. The construction process of pedagogical knowledge among nursing professors. Rev Latino-Am Enfermagem [Internet]. 2011 [cited 2015 Apr 20]; 19(2):421-28. Available from: http:/ / www.scielo.br/scielo.php?pid=S010411692011000200026\&script=sci_arttext

17. Delors J, Al-Mufti I, Amagi I, Carneiro R, Chung F, Bronislaw G, et al. Educação: um tesouro a descobrir. São Paulo: Cortez; 1998.

18. Puentes RV, Aquino OF, Neto A.Q. Profissionalização dos professores: conhecimentos, saberes e competências necessários à docência. Educar [Internet]. 2009 [cited 2015 May 15]; (34):169-84. Available from: www.scielo.br/pdf/er/n34/10.pdf

19. Santos SC. O processo de ensino-aprendizagem e a relação professor-aluno: aplicação dos "sete princípios para a boa prática na educação de Ensino superior". Cad Pesqui Adm [Internet]. 2001 [cited 2015 May 15]; 8(1):69-82. Available from: regeusp.com.br/arquivos/ v08-1art07.pdf

20. Freire P. Carta de Paulo Freire aos professores. Estud Av [Internet]. 2001 [cited 2015 May 15]; 15(42):259-68. Available from: http:// www.scielo.br/scielo.php?script $=\mathrm{sci}_{-}$ arttext\&pid=S0103-40142001000200013

21. Pimenta SG. Formação de professores: identidade e saberes da docência. In: Pimenta SG, organizador. Saberes pedagógicos e atividade docente. São Paulo: Cortez; 1999. p. 15-34.

22. Corbellini VL, Santos BRL, Ojewda BS, Gerhart LM, Eidt OR, Stein SC, et al. Nexos e desafios na formação profissional do enfermeiro. Rev Bras Enferm [Internet]. 2010 [cited 2015 Jun 11]; 63(4):555-60. Available from: http:// www.scielo.br/scielo.php?script=sci arttext\&pid=S0034-71672010000400009

23. Viegas LT, Simionato MF, Bridi FSR. Formação de professores: uma análise preliminar do programa nacional de formação continuada de professores da educação básica. Reflex Ação [Internet]. 2009 [cited 2015 Jun 11]; 17(2):69-90. Available from: http:/ / online. unisc.br/seer/index.php/reflex/article/view/1091

24. Cunha MI, Zanchet BBA, Ribeiro GM. Qualidade do ensino de graduação: culturas, valores e seleção de professores. Prax Educ [Internet]. 2013 [cited 2015 Jun 11]; 8(1):219-41. Available from: www.redalyc.org/ pdf/894/89427917010.pdf

25. Roldão MC. Função docente: natureza e construção do conhecimento profissional. Rev Bras Educ [Internet]. 2007 [cited 2015 May 09]; 12(34):94-181. Available from: www.scielo.br/pdf/rbedu/v12n34/a08v1234.pdf

26. Masetto MT. Competência pedagógica do professor universitário. São Paulo: Summus Editorial; 2012.

27. Claro JACS, Profeta, RA. Programas de benefícios sociais para docentes no ensino superior brasileiro como forma de reter talentos: um estudo exploratório. Avaliação [Internet]. 2015 [cited 2015 Jun 11]; 20(1):189-223. Available from: www.scielo.br/pdf/ aval/v20n1/1414-4077-aval-20-01-00189.pdf

28. Scheibe L. Formação de professores: dilemas da formação inicial a distância. Revista de Educação. Educere Educ [Internet]. 2006 [cited 2015 Jun 11]; 1(2):199-212. Available from: www.abed.org.br/ congresso2013/cd/20.doc

29. Zabalza MA. O ensino universitário: seu cenário e seus protagonistas. Porto Alegre (RS): Artmed; 2004.

30. Backes VMS, Moya JLM, Prado ML, Menegaz JC, Cunha AP, Francisco BS. Expressions of pedagogical content knowledge of an experienced nursing teacher. Texto Contexto Enferm [Internet]. 2013 [cited 2015 Nov 17]; 22(3):804-10. Available from: http://www. scielo.br/pdf/tce/v22n3/v22n3a29.pdf

31. Nóvoa A. Nada substitui um bom professor: propostas para uma revolução no campo da formação de professores [Internet]. São Paulo: SINPRO-SP, 2006 [cited 2015 Jun 22]. Palestra em homenagem ao Dia Mundial do Professor. Available from: vinicius. pro.br/novoa/wp-content/uploads/2014/09/ Apresentação.pdf

32. Araújo Madeira MZ, Lima, MGSB. O significado da prática docente na constituição do saber ensinar das professoras do curso de enfermagem da Universidade Federal do Piauí. Texto Contexto Enferm [Internet]. 2010 [cited 2015 Jun 22]; 19(1):70-7. Available from: www.scielo.br/pdf/tce/v19n1/v19n1a08.pdf

33. Caregnato RCA, Martini RMF, Mutti RMV. Questão ético-moral na formação dos enfermeiros e médicos: efeitos de sentidos nos discursos docentes. Texto Contexto Enferm [Internet]. 2009 [cited 2015 Jun 22]; 18(4):713-21. Available from: www.scielo.br/pdf/ tce/v18n4/13.pdf 